University of Nebraska - Lincoln

DigitalCommons@University of Nebraska - Lincoln

\title{
Changes in Soil Attributes Following Low Phosphorus Swine Slurry Application to No-Tillage Sorghum
}

Brian J. Wienhold

University of Nebraska-Lincoln, Brian.Wienhold@ars.usda.gov

Follow this and additional works at: https://digitalcommons.unl.edu/usdaarsfacpub

Wienhold, Brian J., "Changes in Soil Attributes Following Low Phosphorus Swine Slurry Application to NoTillage Sorghum" (2005). Publications from USDA-ARS / UNL Faculty. 1220.

https://digitalcommons.unl.edu/usdaarsfacpub/1220

This Article is brought to you for free and open access by the U.S. Department of Agriculture: Agricultural Research Service, Lincoln, Nebraska at DigitalCommons@University of Nebraska - Lincoln. It has been accepted for inclusion in Publications from USDA-ARS / UNL Faculty by an authorized administrator of DigitalCommons@University of Nebraska - Lincoln. 


\title{
Changes in Soil Attributes Following Low Phosphorus Swine Slurry Application to No-Tillage Sorghum
}

\author{
Brian J. Wienhold*
}

\begin{abstract}
Swine (Sus scrofa) slurry can serve as an excellent fertilizer source. Application at rates to meet crop $\mathbf{N}$ requirements can result in excess soil $P$ due to low manure N/P ratios. Low phytate corn (LPC) (Zea mays L.) stores a greater proportion of $\mathbf{P}$ as phosphate than does traditional corn (TC) increasing bioavailability of $P$ in pig feed grain. Improved utilization of feed $P$ reduces $P$ concentration in manure and soil P accumulation. However, the potential effects of LPC manure on other soil properties are not known. Changes in soil attributes over $3 \mathrm{yr}$ were compared for soils receiving LPC manure, TC manure, inorganic fertilizer, and no nutrients in no-tillage sorghum [Sorghum bicolor (L.) Moench] on a Sharpsburg clay loam (fine, smectitic, mesic Typic Argiudolls). Soil physical properties exhibited values that should not inhibit crop growth. Several soil chemical properties differed by year and treatment. Particulate organic matter (POM), $\mathrm{NO}_{3}-\mathrm{N}$, $\mathrm{pH}$, and extractable $P$ increased with manure additions. Extractable $P$ content was greater with addition of TC than LPC manure. Soil chemical properties exhibited values acceptable for crop production, but increasing extractable $P$ increases the potential for environmental contamination. Biological soil properties varied in their response to treatments. Microbial biomass $\mathbf{C}$ decreased in the control and increased in manure treatments. The Soil Management Assessment Framework (SMAF) was used to conduct a dynamic soil quality assessment. The SMAF index values were similar across years in the control and inorganic fertilizer treatments and increased in both manure treatments. Manure additions improved soil properties affecting crop production, with $P$ accumulation and the potential for environmental contamination being lower with LPC manure. LPC manure applied at rates to meet crop $\mathbf{N}$ requirements will have slower soil $P$ accumulation rates and a lower potential for $P$ contamination of the environment.
\end{abstract}

$\mathrm{S}^{\mathrm{w}}$ WINE SLURRY CONTAINS nutrients essential for plant growth and when applied to soil at proper rates can serve as an excellent source of essential plant nutrients. When applied to land at rates in excess of that needed by the crop, the potential exists for water soluble $\mathrm{P}$ and $\mathrm{NO}_{3}-\mathrm{N}$ to leach and for increased runoff losses of all fractions of $\mathrm{N}$ and $\mathrm{P}$ (Sharpley et al., 1998). Application of swine manure to meet crop $\mathrm{N}$ needs can result in the accumulation of inorganic $\mathrm{P}$ because the N/P ratio in swine manure is lower than that needed by most crops. The low N/P ratio in swine manure results from the inability of swine to efficiently utilize phytate $\mathrm{P}$, the primary form of $\mathrm{P}$ stored in TC. Low phytate corn contains a mutant gene that results in grain containing simi-

USDA-ARS, Soil and Water Conservation Research Unit, Lincoln, NE 68583. Contribution of USDA-ARS and Univ. of Nebraska-Lincoln. Journal Ser. no. 14104. U.S. Department of Agriculture, Agriculture Research Service, Northern Plains Area, is an equal opportunity/ affirmative action employer and all agency services are available without discrimination. Received 15 Mar. 2004. *Corresponding author (bwienhold1@unl.edu).

Published in Soil Sci. Soc. Am. J. 69:206-214 (2005).

(C) Soil Science Society of America

677 S. Segoe Rd., Madison, WI 53711 USA lar amounts of total $\mathrm{P}$ as TC, but a larger proportion of that $\mathrm{P}$ exists as phosphate rather than phytate (Ertl et al., 1998). Bioavailability of P in LPC is higher than in TC for nonruminant animals such as swine (Baxter et al., 1998) and poultry (Ertl et al., 1998). Increased bioavailability of feed $\mathrm{P}$ reduces the need for supplemental $\mathrm{P}$ in the diet and results in less $\mathrm{P}$ being excreted by the animal (Baxter et al., 1998). In a laboratory study, Gollany et al. (2003) found that P content of LPC swine manure was $42 \%$ lower than TC swine manure, but $\mathrm{P}$ availability was similar. However, potential effects of LPC swine manure on soil properties have not been adequately assessed in the field.

In addition to nutrients, manure contains organic matter and minerals. Addition of manure to soils can directly or indirectly affect soil physical, chemical, and biological properties. Direct effects include changes in nutrient status or $\mathrm{pH}$. Indirect effects may result from altered microbial activity, soil organic matter status, and rates of nutrient mineralization. In a laboratory study, Dendooven et al. (1998) reported that immediately after addition of swine slurry soil $\mathrm{pH}$ increased from 6.2 to 7.1 , increased to 8.3 after $3 \mathrm{~d}$, and then declined to 7.4 after 28 d. Dendooven et al. (1998) also reported no increase in soil $\mathrm{NO}_{3}-\mathrm{N}$ concentration $28 \mathrm{~d}$ after slurry application. Several studies have reported short-term increases in microbial biomass C (Lalande et al., 2000; Rochette et al., 2000a), increased enzyme activity (Lalande et al., 2000), and increased C mineralization (Dendooven et al., 1998) following swine slurry addition, but these increases did not persist. Rochette et al. (2000a) described two phases in swine slurry organic matter decomposition. Initial rates of decomposition were rapid, proportional to application rates, and involved readily decomposable organic compounds. During the second phase, decomposition was slower and involved more recalcitrant compounds. Two months after slurry application, microbial biomass $\mathrm{C}$ concentrations in soils receiving swine slurry were similar to those receiving inorganic fertilizer. Flowers and Arnold (1983) reported that $\mathrm{N}$-mineralization rates in swine-slurry-amended soil were similar to untreated controls. Since the chemical composition of TC and LPC manure differs (Wienhold and Miller, 2004), studies are needed to determine if these manure types differ in their effects on soil quality.

Assessing management effects on soil quality is complicated by the often conflicting results exhibited by individual soil attributes (Andrews et al., 2002). Management assessment is best done using a dynamic assessment so that temporal variation in attributes and trends

Abbreviations: $D_{b}$, bulk density; $E C$, electrical conductivity; $G_{w}$, gravimetric water content; LPC, low phytate corn; PD, particle density; POM, particulate organic matter; SMAF, soil management assessment framework; TC, traditional corn; WFPS, water-filled pore space. 
in changes associated with management practices can be detected (Larson and Pierce, 1994). Combining results for a variety of attributes into an index can be effective in resolving conflicting results and assist in assessing management effects (Karlen and Stott, 1994). Andrews et al. (2002) rigorously compared a number of indexing approaches and concluded that management practices could be assessed using a small number of key indicators with an additive index utilizing nonlinear scoring curves for the indicators. Andrews and Carroll (2001) used a similar index to assess poultry litter management alternatives.

Since the effects of LPC swine manure on soil attributes have not been assessed under field conditions, the objectives of this study were to: (i) compare soil physical, chemical, and biological properties in soils receiving TC or LPC swine manure, inorganic fertilizer, or no additional nutrients over $3 \mathrm{yr}$ in soils that had received only inorganic fertilizer and no manure for at least $10 \mathrm{yr}$; (ii) determine if TC and LPC manure differed in their effect on soil properties; and (iii) implement the Soil Management Assessment Framework (SMAF) of Andrews et al. $(2002,2004)$ as a means of making a dynamic assessment of management effects on soil quality.

\section{MATERIALS AND METHODS}

\section{Swine Feed Preparation}

Corn exhibiting the low phytate trait (Pioneer ${ }^{1}$ variety X1127PP; Pioneer Hybrid International, Johnston, IA) and the same variety without the low phytate trait (Pioneer variety Alicia; Pioneer Hybrid International, Johnston, IA) were grown under irrigation near Shelton, NE in 1998. Recommended practices for irrigation, fertilizer application, and pest control were used to optimize yield. The stands were harvested and stored separately until used as feed. The two corn sources were used to prepare feed appropriate for a starter phase swine diet in the spring of 1999, 2000, and 2001. Each year the two diets were fed to swine in elevated pens with 10 pigs per pen. Each diet was fed to all pigs in six randomly assigned pens. Trays were placed under each pen and slurry (manure and urine) was collected. Slurry from swine fed each of the two diets was stored separately until needed for field application.

\section{Site Description and Experimental Design}

The field site was located at the Roger's Memorial Research Farm $10 \mathrm{~km}$ east of Lincoln, NE. Soil at this site is a Sharpsburg clay loam on a 3 to $5 \%$ slope. Annual precipitation at the site averages $723 \mathrm{~mm}$. Precipitation was near the average in 1999 $(729 \mathrm{~mm})$ and was well below average in $2000(496 \mathrm{~mm})$ and $2001(546 \mathrm{~mm})$.

The site has been in a no-tillage winter wheat (Triticum aestivum L.), soybean [Glycine max (L.) Merr.], sorghum rotation for $>10 \mathrm{yr}$ and was in the sorghum phase of the rotation in the year before the initiation of this study. Four nutrient treatments (inorganic fertilizer, LPC manure, TC manure, and control) were applied in 1999, 2000, and 2001 to 3.6 by $9.7 \mathrm{~m}$ plots arranged in a completely randomized design with three replications. No nutrients were added to the control treatment, $120 \mathrm{~kg} \mathrm{~N} \mathrm{ha}^{-1}$ as $\mathrm{NH}_{4} \mathrm{NO}_{3}$ and $30 \mathrm{~kg} \mathrm{Pha}^{-1}$ as superphosphate

${ }^{1}$ Trade or manufacturer's names mentioned do not constitute endorsement, recommendation, or exclusion by USDA-ARS. were added to the inorganic fertilizer treatments, and both manures were added at rates to meet the $\mathrm{N}$ needs of sorghum assuming $70 \%$ of the $\mathrm{N}$ in the manure was available to the crop during the growing season (Koelsch and Shapiro, 1997). The two manures differed in nutrient concentration (Wienhold and Miller, 2004) and this difference resulted in the application of $180 \mathrm{~kg} \mathrm{~N} \mathrm{ha}^{-1}$ and $50 \mathrm{~kg} \mathrm{P} \mathrm{ha}^{-1}$ in the TC manure treatment and $180 \mathrm{~kg} \mathrm{~N}^{-1}$ and $38 \mathrm{~kg} \mathrm{P} \mathrm{ha}^{-1}$ in the LPC manure treatment. Sorghum was direct-seeded into the previous years residue in mid-May each year and treatments were surface applied at crop emergence (e.g., last week of May).

\section{Soil Sampling Procedures}

In 1999, 2000, 2001, and 2002, one week before planting, soil samples were collected from each plot. Soil samples collected in 1999 represent baseline values before any treatments were imposed. Thirty cores $20 \mathrm{~mm}$ in diameter were collected to a depth of $30 \mathrm{~cm}$ and 15 cores were collected to a depth of $15 \mathrm{~cm}$ were collected from each plot so that one-third of the cores were collected from within the crop row, one-third of the cores were collected from within wheel traffic interrow areas, and one-third of the cores were collected from within non-wheel traffic inter-row areas. The 15 cores collected to a depth of $15 \mathrm{~cm}$ were to ensure that a sufficient mass of soil was collected from the surface layers. Cores were sectioned into 0- to 7.5-, 7.5- to 15-, and 15- to 30-cm depths and composited by depth. Samples were stored at $5^{\circ} \mathrm{C}$ until analyzed for water content and biological properties. Remaining soil was air-dried, ground and passed through a 2-mm sieve.

\section{Soil Property Determination}

Soil physical properties measured included gravimetric water content $\left(G_{w}\right)$ and bulk density $\left(D_{b}\right)$. Water content was determined by measuring mass lost during drying at $105^{\circ} \mathrm{C}$ for $48 \mathrm{~h}$ (Gardner, 1986). Bulk density was calculated by dividing the mass of soil, corrected for moisture content, by the volume of soil collected (Blake and Hartge, 1986). Water content and $\mathrm{D}_{\mathrm{b}}$ were used to calculate water-filled pore space (WFPS) using the equation:

$$
\text { WFPS }=\frac{D_{b} \times G_{w}}{1-\left(D_{b} / P D\right)}
$$

assuming a particle density (PD) of $2.65 \mathrm{~g} \mathrm{~cm}^{-3}$ (Linn and Doran, 1984).

Soil chemical properties measured included $\mathrm{pH}$, electrical conductivity (EC), organic C, total N, labile C, inorganic N, extractable $\mathrm{P}$, and particulate organic matter (POM). Distilled water was added on a $1: 1 \mathrm{w} / \mathrm{w}$ basis to $10 \mathrm{~g}$ of air-dried soil, EC of the soil slurry was determined using a conductivity meter (Rhoades, 1982), and $\mathrm{pH}$ was then determined using a glass electrode (McLean, 1982). Total C and N were determined by dry combustion using a Carlo-Erba NA 1500 NCS (Carlo Erba Instruments, Milan, Italy) analyzer (Schepers et al., 1989). Carbonates were not present based on treatment of the soil with dilute acid and total $\mathrm{C}$ was assumed to represent organic C. Labile $\mathrm{C}$ was measured using the $\mathrm{KMnO}_{4}$ oxidation method (Weil et al., 2003). Inorganic $\mathrm{N}$ in $1 \mathrm{M} \mathrm{KCl}$ extracts was measured colorimetrically using a Lachat flow injection ion analyzer (Zellweger Analytics, Lachat Instruments Div., Milwaukee, WI). Nitrate-N was determined using the $\mathrm{Cd}$ reduction method (Mulvaney, 1996). Particulate organic matter in the $<0.5$ - and 0.5 - to 2 -mm fractions was determined using the method of Cambardella et al. (2001). Extractable P was determined using the method of Bray and Kurtz (1945) with 
$\mathrm{P}$ concentration determined spectrophotometrically at $882 \mathrm{~nm}$ using the phosphomolybdate blue method (Murphy and Riley, 1962).

Soil biological properties measured included potentially mineralizable $\mathrm{N}$ and microbial biomass $\mathrm{C}$ and $\mathrm{N}$. Potentially mineralizable $\mathrm{N}$ was measured using the anaerobic incubation method (Keeney, 1982). Microbial biomass N and C were determined using the microwave irradiation method (Islam and Weil, 1998).

Soil chemical and biological properties are reported on a volumetric basis and were calculated using measure $D_{b}$ values. Results are reported as treatment means \pm standard error of the mean.

\section{Soil Quality Index}

The SMAF of Andrews et al. $(2002,2004)$ was used to calculate an index that integrates transformed values for the various soil attributes and can be used to make comparisons among the various treatments. The assessment framework scores each soil attribute using a nonlinear scoring curve with a baseline and threshold level based on inherent soil properties that describe the relationship between the indicator value and soil function. Scoring curves take one of three forms: moreis-better (e.g., organic $\mathrm{C}$, microbial biomass $\mathrm{C}$, and potentially mineralizable N), less-is-better (e.g., bulk density), or midpoint optimum (e.g., $\mathrm{pH}$, and extractable $\mathrm{P}$ ). The score values for individual attributes were compared among treatments over the $4 \mathrm{yr}$ of the study. In addition, the score values for the individual attributes were summed to provide a SMAF index value for each treatment in each of the $4 \mathrm{yr}$ of the study. In this study, the following specific indicators from the 0- to 15-cm depth were used: total organic $\mathrm{C}$, microbial biomass $\mathrm{C}$, potentially mineralizable $\mathrm{N}, \mathrm{pH}$, bulk density, $\mathrm{EC}$, and extractable $\mathrm{P}$. These indicators were selected because scoring functions for these indicators have been developed as part of the assessment framework and because they have implications for soil functions related to crop production and environmental quality.

\section{Statistical Analysis}

Soil attributes and index outcomes were compared among treatments by a completely random repeated measures model in PROC MIXED of SAS (Littell et al., 1996). Since soil attributes are known to differ with depth, depth was not included in the statistical model and separate statistical analyses were performed for each depth increment. Scoring curves in the SMAF were created using soil property data for the 0 - to 15-cm depth (Andrews et al., 2004). Soil data from the upper two soil increments were averaged. These averaged values were used as input values in the scoring curves to generate scored values. A statistical analysis was performed on both the 0 - to $15-\mathrm{cm}$ soil property data and scored data so that results for soil attributes and results for scored values could be compared. Attribute values for the three depths were also summed and a separate statistical analysis was performed for the 0 - to $30-\mathrm{cm}$ depth to assess if treatment effects were detectable for the entire sampled profile. Differences were declared significant at the 0.05 probability level. Differences among means were determined by pair-wise comparisons made with the DIFF option of the LSMEANS statement. The Tukey adjustment option of the LSMEANS statement was used to protect the experiment-wise error rate.

\section{RESULTS AND DISCUSSION Soil Physical Properties}

Gravimetric soil water content differed among years (data not shown) likely due to differences in precipitation and temperature among years. Soil $D_{b}$ differed among years (Table 1 ). While the differences in $D_{b}$ were statistically significant, the difference was $<0.2 \mathrm{~g} \mathrm{~cm}^{-3}$ and likely resulting from variation in shrink-swell and freeze thaw cycles from year-to-year. Measured $D_{b}$ was below the $1.65 \mathrm{~g} \mathrm{~cm}^{-3}$ threshold for restricting root growth in a clay loam (Arshad et al., 1996). Water-filled pore space in the $0-$ to $7.5-\mathrm{cm}$ depth ranged from 0.50 to 0.72 . Below $7.5 \mathrm{~cm}$, WFPS varied from 0.69 to 0.98 . When WFPS exceeds 0.60 , anaerobic conditions increase in predominance and the potential for microbial processes such as denitrification increase (Linn and Doran, 1984).

\section{Soil Chemical Properties}

Organic $\mathrm{C}$ and total $\mathrm{N}$ increased slightly over the $3 \mathrm{yr}$ in the 0 - to 7.5- and 7.5- to $15-\mathrm{cm}$ increments and did not change over time in the $15-$ to $30-\mathrm{cm}$ increment. Organic C and total $\mathrm{N}$ content in the 0 - to $30-\mathrm{cm}$ depth did not change from 1999 to 2002 . Averaged over years, the organic $\mathrm{C}$ content was $66.2 \pm 1.1 \mathrm{Mg} \mathrm{ha}^{-1}$ and total $\mathrm{N}$ content was $5.7 \pm 0.1 \mathrm{Mg} \mathrm{ha}^{-1}$ in the 0 - to 30 -cm depth increment. In general, soil organic $\mathrm{C}$ and total $\mathrm{N}$ contents change relatively slowly. Varvel (1994) reported an 0.85-g $\mathrm{kg}^{-1}$ increase in $\mathrm{C}$ concentration in a soybean-sorghum rotation compared with an increase of $1.63 \mathrm{~g} \mathrm{~kg}^{-1}$ in continuous dryland sorghum over $8 \mathrm{yr}$ on similar soils. In that study, soils were disked before planting each spring, while no tillage was used in the present study. Tillage creates a more oxidative soil environment resulting in increased organic matter decomposition (Doran, 1980). Numerous studies have shown that soil organic $\mathrm{C}$ accumulation occurs more rapidly in surface soils with notillage than with tillage (e.g., Blevins et al., 1983; Havlin et al., 1990). Over time, we would expect organic $\mathrm{C}$ and $\mathrm{N}$ to increase under no-tillage sorghum.

In this study, two pools, labile C and POM, which contribute to organic soil $\mathrm{C}$ were measured. Labile $\mathrm{C}$ was similar across years and treatments in all threedepth increments and averaged $900 \pm 24 \mathrm{~kg} \mathrm{ha}^{-1}$ for the 0 - to $30-\mathrm{cm}$ depth. Labile $\mathrm{C}$ is being proposed as a

Table 1. Soil bulk density as a function of year and depth in rainfed no-tillage sorghum in eastern Nebraska.

\begin{tabular}{|c|c|c|c|}
\hline \multirow[b]{2}{*}{ Year } & \multicolumn{3}{|c|}{ Depth increment } \\
\hline & 0 to $7.5 \mathrm{~cm}$ & 7.5 to $15 \mathrm{~cm}$ & 15 to $30 \mathrm{~cm}$ \\
\hline & \multicolumn{2}{|c|}{ 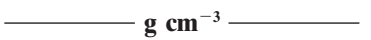 } & \\
\hline 1999 & $\mathbf{1 . 3 3} \pm \mathbf{0 . 0 2} \mathrm{c} \dagger$ & $1.36 \pm 0.02$ b & $1.43 \pm 0.01 \mathrm{~b}$ \\
\hline 2000 & $1.21 \pm 0.02 \mathrm{~b}$ & $1.38 \pm 0.01 \mathrm{~b}$ & $1.38 \pm 0.02 a b$ \\
\hline 2001 & $1.11 \pm 0.02 \mathrm{a}$ & $1.30 \pm 0.02 \mathrm{a}$ & $1.35 \pm 0.02 \mathrm{a}$ \\
\hline 2002 & $1.20 \pm 0.01 b$ & $1.44 \pm 0.02 \mathrm{c}$ & $1.49 \pm 0.02 \mathrm{c}$ \\
\hline \multicolumn{4}{|l|}{ Effect } \\
\hline Treatment & 0.48 & 0.54 & 0.09 \\
\hline Year & $<\mathbf{0 . 0 1}$ & $<\mathbf{0 . 0 1}$ & $<\mathbf{0 . 0 1}$ \\
\hline Treatment $\times$ year & 0.68 & 0.55 & 0.17 \\
\hline
\end{tabular}

+ Mean \pm standard error of the mean. Values in a column followed by the same letter are not different at $P \leq 0.05$. 
method for estimating active $\mathrm{C}$ in soil quality assessments (Weil et al., 2003). Labile $\mathrm{C}$ has been strongly correlated with substrate-induced respiration, microbial biomass, and soluble carbohydrate $\mathrm{C}$, and less strongly correlated with basal respiration, total organic $\mathrm{C}$, and $\mathrm{K}_{2} \mathrm{SO}_{4}$-extractable $\mathrm{C}$ (Weil et al., 2003). In this study, differences among treatments and years in labile $\mathrm{C}$ were too small to detect when measured 11 mo after slurry application. This is consistent with others reporting that the increase in microbial biomass $\mathrm{C}$ (Lalande et al., 2000; Rochette et al., 2000a), enzyme activity (Lalande et al., 2000), and C mineralization (Dendooven et al., 1998) following swine slurry addition did not persist.

In contrast to labile $\mathrm{C}, \mathrm{POM}$ differed among treatments and years. From 1999 to 2002, the $<0.5$-mm POM content declined in the control treatment in the 0 - to 7.5- and 15- to 30-cm depths (data not shown). From 1999 to 2002, the 0.5- to 2-mm POM and total POM increased in the fertilizer and manure treatments in the 0 - to $7.5-\mathrm{cm}$ depth. In the 7.5- to $15-\mathrm{cm}$ depth, the $<0.5 \mathrm{~mm}$ POM, 0.5- to 2-mm POM, and total POM content was similar among treatments and years (data not shown). In the 0 - to $30-\mathrm{cm}$ depth, the $<0.5-\mathrm{mm}$ POM and total POM decreased from 1999 to 2002 and the 0.5 - to 2-mm POM was similar among years in the control treatment (Fig. 1). In the inorganic fertilizer, TC manure, and LPC manure treatments the 0.5- to



Fig. 1. Small $(<0.5 \mathrm{~mm})$, large $(0.5-2 \mathrm{~mm})$, and total particulate organic matter (POM) as a function of nutrient treatment and year for the 0- to 30-cm depth increment. Bars within a POM size and treatment group with different letters above them are different at $\boldsymbol{P}<\mathbf{0 . 0 5}$. 2-mm POM increased from 1999 to 2002 and was greater than in the control (Fig. 1). In the inorganic fertilizer treatment, total POM varied from year to year, but did not change from 1999 to 2002. In the TC manure and LPC manure treatments, total POM increased from 1999 to 2002 (Fig. 1).

Besnard et al. (1996) described POM as a labile fraction of soil organic matter that is physically protected from biodegradation within soil aggregates. Wander et al. (1994) identified POM as a measure of less active labile soil organic matter. Physical protection making POM less labile would explain why observed differences in POM were not expressed as differences in labile C above. Cattle manure additions to soil have been shown to increase water stability of macroaggregates with these macroaggregates exhibiting increased organic $\mathrm{C}$ concentrations in the form of POM (Aoyama et al., 1999). Changes in POM associated with swine slurry additions have not been reported. In this study, the decline in POM in the control treatment is likely due to declining yields associated with reduced nutrient availability. Increases in POM in the fertilizer and manure treatments are likely due to maintaining sorghum yields with adequate nutrient availability.

Electrical conductivity (range 0.07 to $0.67 \mathrm{dS} \mathrm{m}^{-1}$ ) differed by year in all three soil depth increments (data not shown). Nutrient treatments did not affect EC in the 0 - to $7.5-\mathrm{cm}$ depth. However, in the 7.5- to $15-$ and 15- to 30-cm depths, EC was similar in the control and inorganic fertilizer treatments, but was greater in the TC manure and LPC manure treatments (data not shown). The increase in EC is likely due to the higher $\mathrm{NO}_{3}-\mathrm{N}$ contents described below. The observed EC values were well below threshold levels for reducing crop yield (Maas and Hoffman, 1977) or increasing microbial release of nitrous oxide (Smith and Doran, 1996).

Soil $\mathrm{pH}$ differed by treatment and year in the 0 - to $7.5-\mathrm{cm}$ depth and by year in the 7.5- to 15- and 15- to $30-\mathrm{cm}$ depths. In the $0-$ to $7.5-\mathrm{cm}$ depth, $\mathrm{pH}$ was lower in the inorganic fertilizer treatment than in the other treatments (data not shown). Treatment effects on soil $\mathrm{pH}$ in the surface layer are likely the result of proton $\left(\mathrm{H}^{+}\right)$production during nitrification of ammonical fertilizer in the inorganic fertilizer treatment (Adams, 1984) compared with the liming effect of manure produced by animals fed rations with mineral supplements in the two manure treatments (Dendooven et al., 1998). While there were observed soil $\mathrm{pH}$ differences among the treatments, the soil $\mathrm{pH}$ in all treatments and years was within the range favorable for nutrient availability and sorghum production (Smith and Doran, 1996).

Soil inorganic $\mathrm{N}$ content differed by year for all depths. In the 0 - to $30-\mathrm{cm}$ depth, soil $\mathrm{NO}_{3}-\mathrm{N}$ content was greater in 2000 than in 1999 and 2001 (Table 2). In the 0- to 7.5-cm depth increment, $\mathrm{NO}_{3}-\mathrm{N}$ content was greater in the TC manure treatment than in the inorganic fertilizer and control and the LPC manure treatment is greater than the inorganic fertilizer treatment (Table 2). In the 7.5- to $15-\mathrm{cm}$ depth increment $\mathrm{NO}_{3}-\mathrm{N}$ content was greater in the two manure treatments than in the inorganic fertilizer and control. In the $15-$ to $30-\mathrm{cm}$ depth 
Table 2. Soil $\mathrm{NO}_{3}-\mathrm{N}$ content as a function of year and nutrient treatment in rainfed no-tillage sorghum in eastern Nebraska.

\begin{tabular}{|c|c|c|c|c|c|}
\hline \multirow[b]{2}{*}{ Year } & \multicolumn{4}{|c|}{ Treatment } & \multirow[b]{2}{*}{ Year mean } \\
\hline & Control & Inorganic fertilizer & Traditional manure & Low phytate manure & \\
\hline \multicolumn{2}{|c|}{0 to $7.5 \mathrm{~cm}$} & & & & \\
\hline 1999 & 6.5 a $\mathrm{A} \dagger$ & 6.6 a $\mathrm{A}$ & 6.7 a $\mathrm{A}$ & 6.0 a $\mathrm{A}$ & $6.5 \neq \pm 0.2 \mathrm{~A}$ \\
\hline 2000 & 10.6 a A & 6.1 a A & 15.6 a A & 11.1 a $\mathbf{A}$ & $10.9 \pm 1.0 \mathrm{~B}$ \\
\hline 2001 & 2.9 a A & 3.8 a A & 5.8 a A & 4.9 a $\mathrm{A}$ & $4.4 \pm 0.4 \mathrm{~A}$ \\
\hline 2002 & $4.6 \mathrm{a} \mathrm{A}$ & 5.5 a A & 6.5 a A & 8.4 a $\mathrm{A}$ & $6.3 \pm 0.6 \mathrm{AB}$ \\
\hline Treatment mean & $6.2 \pm 0.6 \mathrm{~b}$ & $5.5 \pm 0.6 \mathrm{a}$ & $8.7 \pm 0.7 c$ & $7.6 \pm 0.7 \mathrm{bc}$ & \\
\hline \multicolumn{6}{|c|}{7.5 to $15 \mathrm{~cm}$} \\
\hline 1999 & 3.0 a $\mathbf{A}$ & 2.6 a $\mathrm{A}$ & 2.9 a $\mathrm{A}$ & 2.6 a $\mathrm{A}$ & $2.8 \pm 0.1 \mathrm{~A}$ \\
\hline 2000 & 2.7 a A & 2.8 a A & 6.5 a B & 4.8 a A & $4.2 \pm 0.5 \mathrm{AB}$ \\
\hline 2001 & 2.1 a A & 2.6 a A & 3.6 a $\mathrm{AB}$ & 4.6 a A & $3.2 \pm 0.2 \mathrm{AB}$ \\
\hline 2002 & 2.5 a A & $4.3 \mathrm{a} \mathrm{A}$ & 6.4 a B & 5.7 a A & $4.7 \pm 0.4 \mathrm{~B}$ \\
\hline Treatment mean & $2.6 \pm 0.4 a$ & $3.1 \pm 0.4 \mathrm{a}$ & $4.9 \pm 0.4 \mathrm{~b}$ & $4.4 \pm 0.4 \mathrm{~b}$ & \\
\hline \multicolumn{6}{|c|}{15 to $30 \mathrm{~cm}$} \\
\hline 1999 & 6.2 a $\mathrm{A}$ & 5.8 a A & 5.7 a A & 4.9 a $\mathrm{A}$ & $5.6 \pm 0.3 \mathrm{~A}$ \\
\hline 2000 & 3.0 a $\mathbf{A}$ & 4.3 a $\mathrm{A}$ & $9.0 \mathrm{~b} \mathrm{~A}$ & 6.5 a A & $5.7 \pm 0.5 \mathrm{~A}$ \\
\hline 2001 & 5.0 a A & 7.8 a A & 8.0 a $\mathrm{A}$ & 6.8 a A & $6.9 \pm 1.0 \mathrm{AB}$ \\
\hline 2002 & 3.5 a A & 6.2 a A & $9.8 \mathrm{~b} \mathrm{~A}$ & 8.9 b A & $7.1 \pm 0.4 \mathrm{~B}$ \\
\hline Treatment mean & $4.4 \pm 0.6 \mathrm{a}$ & $6.0 \pm 0.6 \mathrm{ab}$ & $8.1 \pm 0.6 \mathrm{c}$ & $6.8 \pm 0.6 \mathrm{bc}$ & \\
\hline \multicolumn{6}{|c|}{0 to $30 \mathrm{~cm}$} \\
\hline 1999 & 15.7 a A & 15.0 a $\mathbf{A}$ & 15.2 a A & 13.5 a $\mathrm{A}$ & $14.9 \pm 0.5 \mathrm{~A}$ \\
\hline 2000 & 16.3 ab A & 13.1 a A & 32.2 b B & 20.2 ab A & $20.5 \pm 1.7 \mathrm{~B}$ \\
\hline 2001 & 9.8 a A & 14.2 a A & 17.5 a $\mathrm{A}$ & 16.4 a A & $14.5 \pm 0.9 \mathrm{~A}$ \\
\hline 2002 & 10.6 a A & 16.0 a $\mathrm{A}$ & 22.6 a AB & 23.0 b A & $18.1 \pm 1.1 \mathrm{AB}$ \\
\hline Treatment mean & $13.2 \pm 1.1 \mathrm{a}$ & $14.6 \pm 1.1 \mathrm{ab}$ & $21.9 \pm 1.1 \mathrm{c}$ & $18.3 \pm 1.2 \mathrm{bc}$ & \\
\hline \multicolumn{6}{|l|}{ Effect } \\
\hline Treatment & 0.02 & $<0.01$ & $<0.01$ & $<0.01$ & \\
\hline Year & $<0.01$ & $<0.01$ & 0.06 & $<0.01$ & \\
\hline Treatment $\times$ year & 0.08 & $<\mathbf{0 . 0 1}$ & $<0.01$ & $<0.01$ & \\
\hline
\end{tabular}

$\dagger$ For each depth increment, means within a row followed by the same lower case letter or means within a column followed by the same upper case letter are not different at $\boldsymbol{P}<\mathbf{0 . 0 5}$.

+ Mean \pm standard error of the mean.

increment $\mathrm{NO}_{3}-\mathrm{N}$ content was greatest in the LPC manure treatment and similar among the other three treatments. When summed across depths, $\mathrm{NO}_{3}-\mathrm{N}$ content was lowest in the control and greatest in the TC manure treatment. Higher $\mathrm{NO}_{3}-\mathrm{N}$ contents in the manure treatments are likely due to the higher $\mathrm{N}$ application rates in those treatments than the $\mathrm{N}$ applied in the inorganic fertilizer treatment. Rochette et al. (2000b) observed similar inorganic $\mathrm{N}$ concentrations in 0 - to $15-\mathrm{cm}$ depth of soils receiving two rates of swine slurry or inorganic fertilizer in the spring before nutrient application. Soil $\mathrm{NH}_{4}-\mathrm{N}$ content varied among years in all three soil increments. In the 0 - to $30-\mathrm{cm}$ depth, $\mathrm{NH}_{4}-\mathrm{N}$ content was $3.7 \mathrm{~kg} \mathrm{ha}^{-1}$ in $1999,5.5 \mathrm{~kg} \mathrm{ha}^{-1}$ in $2000,3.1 \mathrm{~kg} \mathrm{ha}^{-1}$ in 2001 , and $1.4 \mathrm{~kg} \mathrm{ha}^{-1}$ in 2002 . Low soil $\mathrm{NH}_{4}-\mathrm{N}$ content suggests that nitrification activity in these soils was not adversely affected by the EC values measured in these soils.

Soil extractable P content was similar across treatments in all depth increments in 1999 (Table 3). Soil extractable $\mathrm{P}$ content increased with time in the two manure treatments and did not change in the control and inorganic fertilizer treatments resulting in an interaction between treatments and years. Extractable P content in the 0 - to $30-\mathrm{cm}$ depth increased slightly in the inorganic fertilizer treatment and increased two- to three-fold in the manure treatments over the $4 \mathrm{yr}$ of this study. Following three annual manure applications, extractable $\mathrm{P}$ content was greater in the TC manure treatment than in the LPC manure treatment in the 0- to 7.5-, 7.5- to
15-, and 0- to 30-cm increments (Table 3). Differences in extractable $\mathrm{P}$ are a result of differences in $\mathrm{P}$ application rates between the two manure types. While changes in soil extractable $\mathrm{P}$ were greatest in the $0-$ to $7.5-\mathrm{cm}$ increment, surface application of swine slurry affected soil extractable $\mathrm{P}$ throughout the $30-\mathrm{cm}$ sampling zone.

As soil extractable $\mathrm{P}$ content increases, the potential for environmental contamination associated with runoff losses of P also increases (Sharpley et al., 1996). Smaller increases in extractable $\mathrm{P}$ occurred in plots receiving manure from swine fed LPC diets. Lower P accumulation in the LPC manure treatment is the result of lower $\mathrm{P}$ application rates in this treatment. Manure from swine fed LPC diets has a lower P content than does TC manure and N/P ratio (1:4.8) closer to that required by a crop (1:6) than does manure from swine fed a TC corn diet (1:3.7). The chemical composition of manure produced by swine fed LPC diets reduces the overapplication of $\mathrm{P}$ when manure is applied at rates intended to meet the $\mathrm{N}$ needs of the crop (Wienhold and Miller, 2004).

\section{Biological Soil Properties}

Potentially mineralizable $\mathrm{N}$ increased with time in all soil depth increments (Table 4). There were no differences in potentially mineralizable $\mathrm{N}$ among treatments in any of the sampled increments. Apparently, potentially mineralizable $\mathrm{N}$ is not sensitive to swine manure application. Flowers and Arnold (1983) also reported 
Table 3. Soil extractable $P$ content as a function of year and nutrient treatment in rainfed no-tillage sorghum in eastern Nebraska.

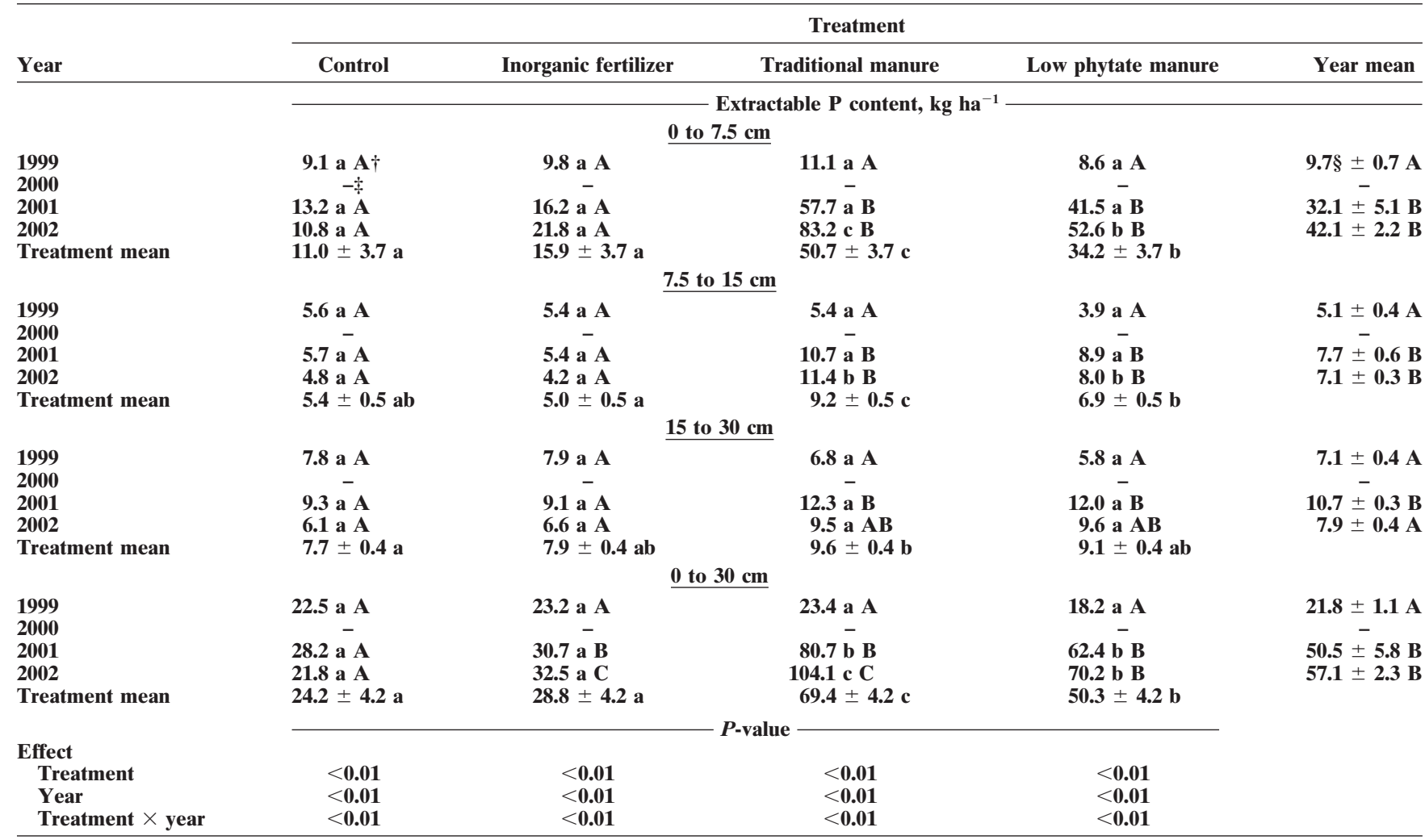

$\dagger$ For each depth increment, means within a row followed by the same lower case letter or means within a column followed by the same upper case letter are not different at $\boldsymbol{P}<\mathbf{0 . 0 5}$.

$\$$ Extractable $P$ not determined in 2000 .

$\S$ Mean \pm standard error of the mean.

that $\mathrm{N}$ mineralization in swine slurry amended soil was similar to untreated controls several months after slurry application.

Microbial biomass $\mathrm{C}$ content exhibited a treatmentby-year interaction for the 0 - to $30-\mathrm{cm}$ depth increment. Microbial biomass C decreased from 1999 to 2002 in the control, exhibited a declining trend from 1999 to 2002 in the inorganic fertilizer treatment, fluctuated among years with no clear trend in the LPC manure treatment, and increased from 1999 to 2002 in the TC manure treatments (Fig. 2). Microbial biomass N content differed by year in all soil increments and was greater in 1999 and 2000 than in 2001 and 2002 in all treatments (Fig. 2).
Previously reported responses of microbial biomass $\mathrm{C}$ and $\mathrm{N}$ to swine slurry additions has been mixed. Rochette et al. (2000a) observed similar microbial C and $\mathrm{N}$ concentrations between control and manured soils in the spring before swine slurry application in a loam soil with an organic $\mathrm{C}$ concentration of $19.9 \mathrm{~g} \mathrm{~kg}^{-1}$ under corn silage production (low residue input). In contrast, Lalande et al. (2000) reported an increase in microbial biomass $\mathrm{C}$ in soils under corn silage production in a silt loam having an organic $\mathrm{C}$ concentration of $32.3 \mathrm{~g} \mathrm{~kg}^{-1}$ that received swine slurry, but no change in soils receiving inorganic fertilizer or no nutrient additions. Initial soil organic matter levels and crop residue inputs likely affect the response of soil microorganisms to swine

Table 4. Potentially mineralizable $\mathbf{N}$ content as a function of year in rainfed no-tillage sorghum in eastern Nebraska.

\begin{tabular}{|c|c|c|c|c|}
\hline \multirow[b]{2}{*}{ Year } & \multicolumn{4}{|c|}{ Depth increment } \\
\hline & 0 to $7.5 \mathrm{~cm}$ & 7.5 to $15 \mathrm{~cm}$ & 15 to $30 \mathrm{~cm}$ & 0 to $30 \mathrm{~cm}$ \\
\hline & \multicolumn{4}{|c|}{ Potentially mineralizable $\mathrm{N}, \mathrm{kg} \mathrm{ha}^{-1}$} \\
\hline $\begin{array}{l}1999 \\
2000 \\
2001 \\
2002\end{array}$ & $\begin{array}{l}21.4 \pm 0.5 \mathrm{a} \dagger \\
31.1 \pm 2.4 \mathrm{c} \\
\mathbf{2 5 . 0} \pm \mathbf{1 . 1} \mathrm{b} \\
\mathbf{3 1 . 4} \pm \mathbf{3 . 0} \mathrm{c}\end{array}$ & $\begin{array}{r}7.7 \pm 0.3 \text { a } \\
8.3 \pm 0.4 \text { a } \\
11.5 \pm 0.9 \text { b } \\
10.3 \pm 0.4 \text { b }\end{array}$ & $\begin{array}{l}13.2 \pm 0.7 \mathrm{~b} \\
11.2 \pm 0.5 \mathrm{a} \\
16.4 \pm 0.7 \mathrm{c} \\
14.5 \pm 0.6 \mathrm{~b}\end{array}$ & $\begin{array}{l}\mathbf{4 2 . 3} \pm \mathbf{0 . 8} \mathbf{a} \\
\mathbf{5 0 . 6} \pm \mathbf{2 . 5} \mathbf{b} \\
\mathbf{5 2 . 9} \pm \mathbf{1 . 4} \mathbf{b} \\
\mathbf{5 6 . 2} \pm \mathbf{2 . 8} \mathrm{b}\end{array}$ \\
\hline \multicolumn{5}{|l|}{ Effect } \\
\hline Treatment & 0.21 & 0.15 & 0.82 & 0.16 \\
\hline Year & $<\mathbf{0 . 0 1}$ & $<\mathbf{0 . 0 1}$ & $<\mathbf{0 . 0 1}$ & $<\mathbf{0 . 0 1}$ \\
\hline Treatment $\times$ year & 0.40 & 0.24 & 0.88 & 0.50 \\
\hline
\end{tabular}

$\dagger$ Mean \pm standard error of the mean. For each depth increment, means within a row followed by the same lower case letter or means within a column followed by the same upper case letter are not different at $P<0.05$. 


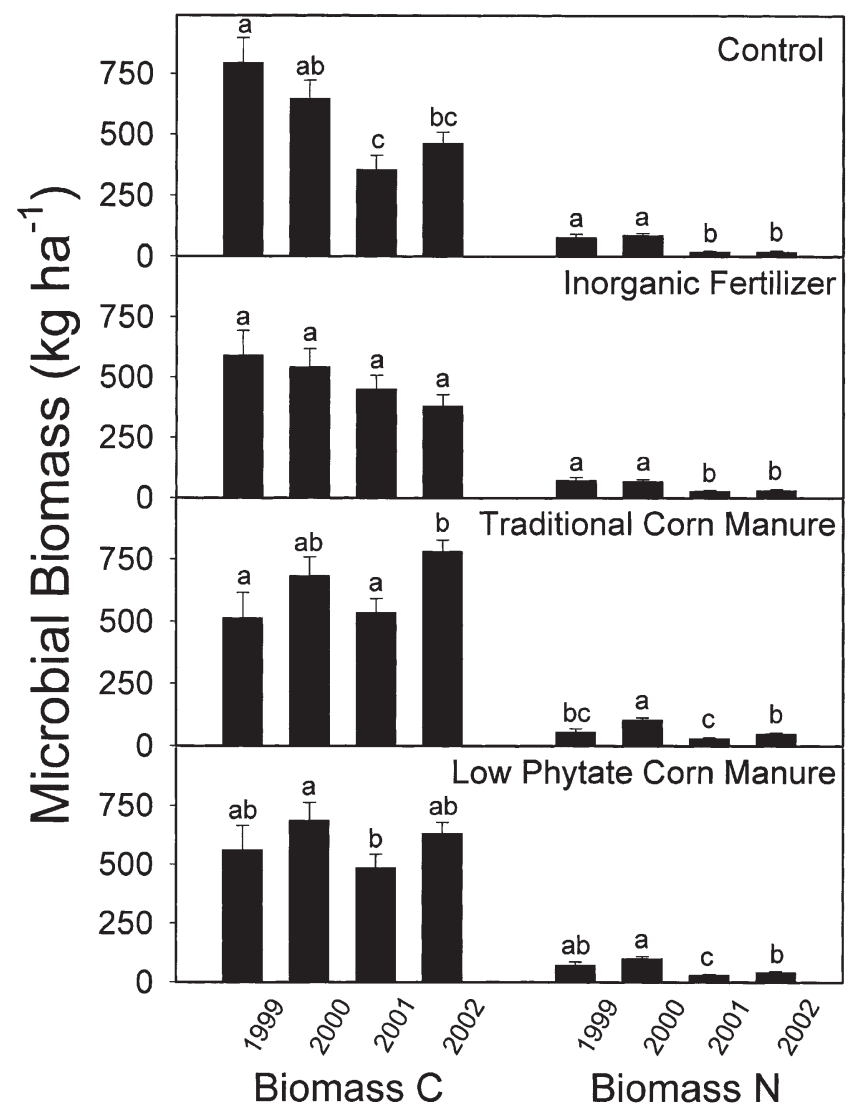

Fig. 2. Microbial biomass $\mathrm{C}$ and $\mathrm{N}$ as a function of nutrient treatment and year for the 0 - to $30-\mathrm{cm}$ depth. Bars within a group with different letters above them are different at $\boldsymbol{P}<0.05$.

slurry additions. The present study was also conducted on a silt loam soil and the observed response of microbial biomass $\mathrm{C}$ to swine slurry and inorganic fertilizer additions were similar to those reported by Lalande et al. (2000). Rochette et al. (2000a) observed a large increase in microbial biomass $\mathrm{C}$ after swine slurry addition followed by a gradual decline throughout the year until the spring when microbial biomass $\mathrm{C}$ was similar to the control. The decline throughout the year was attributed to declining availability of substrate for microbial growth. It seems reasonable that in soils with higher initial organic matter or greater crop residue inputs the increase in microbial biomass $\mathrm{C}$ would be sustained longer. In this study, no-tillage was used and crop residues were maintained on the soil surface throughout the year likely sustaining the microbial biomass response to the swine slurry additions.

\section{Soil Quality Index}

The SMAF index values exhibited a year-by-treatment interaction (Fig. 3). In 1999, there were no differences among index values for the four treatments. The SMAF index values for the control and inorganic fertilizer treatments did not change over the 4 yr of the study. Index values for the two manure treatments increased linearly across years and were greater than those for the control and inorganic fertilizer treatments in 2001 and 2002 (Fig. 3).

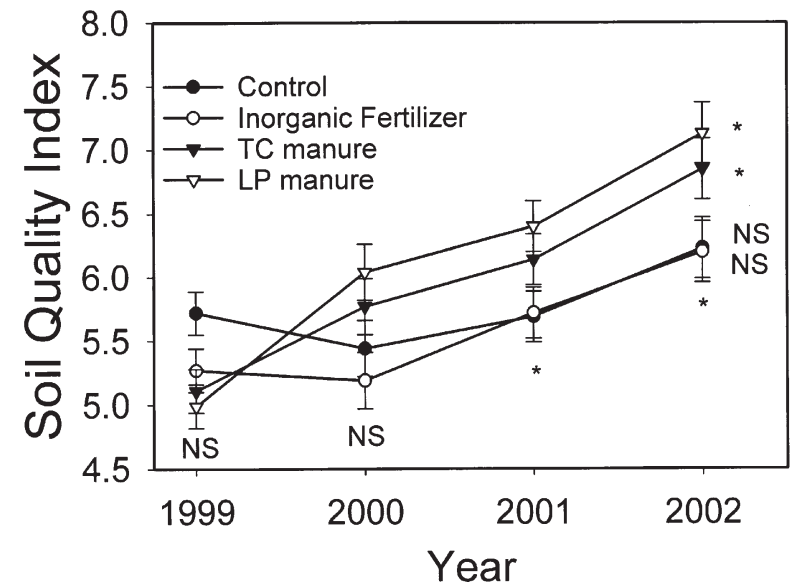

Fig. 3. Changes in the soil quality index as a function of nutrient treatment and year. Error bars represent \pm standard error. Symbols below a group signify no differences (NS) or differences (*) at $\boldsymbol{P}<$ 0.05 among treatments within a year. Symbols to the right of a treatment series signify no difference (NS) or difference (*) at $\boldsymbol{P}<$ 0.05 among years for a treatment.

Increasing SMAF index values over time in the manure treatments resulted from increases in scored values for potentially mineralizable $\mathrm{N}$ and extractable P. Scored values for potentially mineralizable $\mathrm{N}$ also increased in the control and inorganic fertilizer treatments, while those for extractable $\mathrm{P}$ did not, resulting in nonsignificant changes in SMAF index values for those two treatments. An increase in potentially mineralizable $\mathrm{N}$ is desirable for agronomic soils as it implies that there is a labile organic $\mathrm{N}$ pool available to the crop. Manure application increased extractable $\mathrm{P}$ from the ascending part of the scoring curve to the plateau portion of the scoring curve. Continued increases in extractable $\mathrm{P}$ would eventually result in decreasing score values when observed values fell on the descending part of the scoring curve associated with increased potential for environmental contamination.

Analysis of variance results for soil indicators from the 0 - to $15-\mathrm{cm}$ depth were compared with scored values for those indicators (Table 5). Results were similar for organic $\mathrm{C}$, microbial biomass $\mathrm{C}$, extractable $\mathrm{P}$, and $\mathrm{D}_{\mathrm{b}}$, but not for $\mathrm{pH}, \mathrm{EC}$, and potentially mineralizable $\mathrm{N}$. Andrews et al. (2004) described four possible outcomes when indictor results are compared with index results: similar results between observed and scored values, opposite results between observed and scored values, differences in observed indicators, but no differences in scored indicators, and no differences between observed indicators but differences in scored indicators. The first, third, and fourth outcomes were observed in this study.

Similar results between the observed and scored organic $\mathrm{C}$, microbial biomass $\mathrm{C}$, and potentially mineralizable $\mathrm{N}$ indicators occurred because the range of observed values for each of these soil attributes was in the ascending portion of the more-is-better scoring curve and increases in the observed indicator resulted in increases in the score values. Similar results for observed and scored extractable $\mathrm{P}$ occurred because the range of observed values were initially in the ascending portion 
Table 5. Comparison of analysis of variance results for soil attributes (0-15 cm) and index values calculated using the Soil Management Assessment Framework.

\begin{tabular}{|c|c|c|c|c|c|c|}
\hline \multirow[b]{2}{*}{ Indicator $\dagger$} & \multicolumn{3}{|c|}{ Index value } & \multicolumn{3}{|c|}{ Attribute value } \\
\hline & Treatment & Time & Treatment $\times$ time & Treatment & Time & Treatment $\times$ time \\
\hline Organic C & NS $\ddagger$ & **** & NS & NS & $* * *$ & NS \\
\hline MBC & NS & NS & NS & NS & NS & NS \\
\hline Extractable P & $*$ & **** & $* *$ & $* * *$ & $* * *$ & $* * *$ \\
\hline pH & NS & NS & NS & NS & $* * * *$ & NS \\
\hline EC & NS & NS & NS & $*$ & $* * *$ & NS \\
\hline Bulk density & NS & $* * *$ & NS & NS & **** & NS \\
\hline PMN & $*$ & $* * *$ & NS & NS & $* * * *$ & NS \\
\hline
\end{tabular}

* Significant at the 0.05 probability level.

** Significant at the 0.01 probability level.

*** Significant at the 0.001 probability level.

$\dagger$ MBC, microbial biomass C; EC, electrical conductivity; PMN, potentially mineralizable N.

$\uparrow$ NS, not significant

of the local optimum scoring curve. Over time, extractable $\mathrm{P}$ values in the manure treatments increased to the plateau portion of the curve, while those for the control and inorganic fertilizer treatments remained in the ascending portion of the curve resulting in year-by-treatment interactions for both the observed indicator and the scored values. Differences from year-to-year in observed $D_{b}$ and scored values for $D_{b}$ occurred because the observed values were in the descending portion of the less-is-better scoring curve.

The third outcome described by Andrews et al. (2004), differences in observed indicators, but no differences in scored indicators, occurred for the $\mathrm{pH}$ and $\mathrm{EC}$ indicators (Table 5). Measurable differences in $\mathrm{pH}$ and $\mathrm{EC}$ were observed, but these observed values were in the plateau portion of the scoring curve resulting in no differences among scored values. No differences in the scored values means that the observed differences would not be expected to influence soil functions related to agronomic productivity or environmental quality.

The fourth outcome described by Andrews et al. (2004), no differences in observed indicators, but differences in scored indicators, occurred for the potentially mineralizable $\mathrm{N}$ indicator. Differences in potentially mineralizable $\mathrm{N}$ among treatments approached being significant $(P=0.08)$ and the values observed were on the ascending portion of the scoring curve resulting in differences among treatments for the scored indicators.

The SMAF has potential for aiding land managers making dynamic assessments of management practices or for comparing management practices. Scored values for individual soil attributes can be monitored to alert the manager of changes potentially affecting soil functions (e.g., declining $\mathrm{D}_{\mathrm{b}}$ scores alert the manager that compaction problems may be developing). Scored values can also be used to aid in interpreting differences in soil attributes among sampling dates (e.g., help determine if measured differences are meaningful). In this study, observed $\mathrm{pH}$ and $\mathrm{EC}$ values differed among years, but remained within the range of values acceptable for agronomic productivity and environmental quality. As noted above, when scores for individual attributes are summed, the index serves as a tool for comparing management practices.

\section{CONCLUSIONS}

Three years of swine manure application to no-tillage sorghum improved soil quality when compared with control or inorganic fertilizer treatments. The only soil attribute differentially affected by the two manure types was extractable $\mathrm{P}$ in the $0-$ to $7.5-\mathrm{cm}$ depth. Extractable $\mathrm{P}$ increased with both manure types, but the increase was greater with TC than with LPC manure. Extractable $\mathrm{P}$ concentrations exceeding threshold levels would be expected to occur sooner with annual additions of TC manure than with LPC manure. Slower P accumulation rates will allow LPC manure to be spread over a smaller area without increasing the potential for environmental contamination, will reduce manure transportation costs, and will provide $\mathrm{N}$ and $\mathrm{P}$ at a ratio close to what is needed by a sorghum crop.

The soil quality assessment framework (Andrews et al., 2004) was effective in aggregating results for a number of individual soil attributes so that a dynamic assessment of management effects on soil quality could be made (Larson and Pierce, 1994). A dynamic assessment is useful in showing that soil quality was similar among the treatments when the study was initiated and that there was an effect due to manure application. The increase in soil quality in the two manure treatments is attributed to the combined effects of increased potentially mineralizable $\mathrm{N}$, addition of highly available nutrients, and small additions of manure organic matter. Few dynamic assessments of soil quality have been conducted due to the difficulty in interpreting the large data sets that result (Andrews et al., 2002, 2004). Tools such as this soil quality index will facilitate future dynamic assessment studies.

\section{ACKNOWLEDGMENTS}

The author thanks Susan Siragusa and Susan Wagner for technical assistance, Rick and Jeff Pope for access to their swine feeding operation, and Pioneer HiBred International for providing seed.

\section{REFERENCES}

Adams, F. 1984. Crop response to lime in the southern United States. p. 211-265. In F. Adams (ed.) Soil acidity and liming. 2nd ed. Agron. Monogr. No. 12. ASA, CSSA, and SSSA, Madison, WI. Andrews, S.S., and C.R. Carroll. 2001. Designing a soil quality assess- 
ment tool for sustainable agroecosystem management. Ecol. Appl. 11:1573-1585.

Andrews, S.S., D.L. Karlen, and J.P. Mitchell. 2002. A comparison of soil quality indexing methods for vegetable production systems in Northern California. Agric. Ecosyst. Environ. 90:25-45.

Andrews, S.S., D.L. Karlen, and C.A. Cambardella. 2004. The Soil Management Assessment Framework: A quantitative evaluation method with case studies. Soil Sci. Soc. Am. J. 68:1945-1962.

Aoyama, M., D.A. Angers, and A. N'Dayegamiye. 1999. Particulate and mineral-associated organic matter in water-stable aggregates as affected by mineral fertilizer and manure applications. Can. J. Soil Sci. 79:295-302.

Arshad, M.A., B. Lowery, and B. Grossman. 1996. Physical tests for monitoring soil quality. p. 123-141 In J.W. Doran and A.J. Jones (ed.) Methods for assessing soil quality. SSSA Spec. Publ. No. 49. SSSA, Madison, WI.

Baxter, C.A., B.C. Joern, and O. Adeola. 1998. Dietary P management to reduce soil $\mathrm{P}$ loading from pig manure. Proc. North-Central Ext. Ind. Soil Fert. Conf. 14:104-109.

Besnard, E., C. Chenu, J. Balesdent, P. Puget, and D. Arrouays. 1996. Fate of particulate organic matter in soil aggregates during cultivation. Eur. J. Soil Sci. 47:495-503.

Blake, G.R., and K.H. Hartge. 1986. Bulk density. p. 363-375. In A. Klute (ed.) Methods of soil analysis. Part 1. 2nd ed. ASA and SSSA, Madison, WI.

Blevins, R.L., G.W. Thomas, M.S. Smith, W.W. Frye, and P.L. Cornelius. 1983. Changes in soil properties after 10 years of continuous non-tillage and conventionally tilled corn. Soil Tillage Res. 3: 135-136.

Bray, R.H., and L.T. Kurtz. 1945. Determination of total, organic, and available forms of phosphorus in soils. Soil Sci. 59:39-45.

Cambardella, C.A., A.M. Gajda, J.W. Doran, B.J. Wienhold, and T.A. Kettler. 2001. Estimation of particulate and total organic matter by weight loss-on-ignition. p. 349-359. In R. Lal et al. (ed.) Assessment methods for soil carbon. Lewis Publishers, Boca Raton, FL.

Dendooven, L., E. Bonhomme, R. Merckx, and K. Vlassak. 1998. $\mathrm{N}$ dynamics and sources of $\mathrm{N}_{2} \mathrm{O}$ production following pig slurry application to a loamy soil. Biol. Fertil. Soils 26:224-228.

Doran, J.W. 1980. Soil microbial and biochemical changes associated with reduced tillage. Soil Sci. Soc. Am. J. 44:765-771.

Ertl, D.S., K.A. Young, and V. Raboy. 1998. Plant genetic approaches to phosphorus management in agricultural production. J. Environ. Qual. 27:299-304.

Flowers, T.H., and P.W. Arnold. 1983. Immobilization and mineralization of nitrogen in soils incubated with pig slurry or ammonium sulfate. Soil Biol. Biochem. 15:329-335.

Gardner, W.H. 1986. Water content. p. 493-544 In: A. Klute (ed.) Methods of soil analysis Part 1. 2nd ed. ASA and SSSA, Madison, WI.

Gollany, H.T., M.A. Schmitt, P.R. Bloom, G.W. Randall, and P.R. Carter. 2003. Extractable phosphorus following soil amendment with manure from swine fed low-phytate corn. Soil Sci. 168:606-616.

Havlin, J.L., D.E. Kissel, L.D. Maddux, M.M. Claasen, and J.H. Long. 1990. Crop rotation and tillage effects on soil organic carbon and nitrogen. Soil Sci. Soc. Am. J. 54:448-452.

Islam, K.R., and R.R. Weil. 1998. Microwave irradiation of soil for routine measurement of microbial biomass carbon. Biol. Fertil. Soils 27:408-416.

Karlen, D.L., and D.E. Stott. 1994. A framework for evaluating physical and chemical indicators of soil quality. p. 53-72. In J.W. Doran et al. (ed.). Defining soil quality for a sustainable environment. SSSA Spec. Publ. No. 35. SSSA, Madison, WI.

Keeney, D.R. 1982. Nitrogen-Availability indices. p. 711-733. In A.L. Page et al. (ed.) Methods of soil analysis. Part 2. 2nd ed. ASA and SSSA, Madison, WI.
Koelsch, R., and C. Shapiro. 1997. Determining crop available nutrients from manure. NebGuide G97-1335-A University of Nebraska, Lincoln, NE.

Lalande, R., B. Gagnon, R.R. Simard, and D. Cote. 2000. Soil microbial biomass and enzyme activity following liquid hog manure application in a long-term field trial. Can. J. Soil Sci. 80:263-269.

Larson, W.E., and F.J. Pierce. 1994. The dynamics of soil quality as a measure of sustainable management. p. 37-51. In J.W. Doran et al. (ed.). Defining soil quality for a sustainable environment. SSSA Spec. Publ. No. 35. SSSA, Madison, WI.

Linn, D.M., and J.W. Doran. 1984. Effect of water-filled pore space on carbon dioxide and nitrous oxide production in tilled and nontilled soils. Soil Sci. Soc. Am. J. 48:1267-1272.

Littell, R.C., G.A. Milliken, W.W. Stroup, and R.D. Wolfinger. 1996. SAS system for mixed models. SAS Institute, Inc., Cary, NC.

Maas, E.V., and J.G. Hoffman. 1977. Crop salt tolerance-current assessment. J. Irrig. Drain. Div. Am. Soc. Civ. Eng. 103:115-134.

McLean, E.O. 1982. Soil pH and lime requirement. p. 199-224. In A.L. Page et al. (ed.) Methods of soil analysis. Part 2. 2nd ed. ASA and SSSA, Madison, WI.

Mulvaney, R.L. 1996. Nitrogen-Inorganic forms. p. 1123-1184. In D.L. Sparks et al. (ed.) Methods of soil analysis. Part 3. SSSA Book Series No. 5. SSSA Madison, WI.

Murphy, J., and J.P. Riley. 1962. A modified single solution method for the determination of phosphate in natural waters. Anal. Chim. Acta 27:31-36.

Rhoades, J.D. 1982. Soluble salts. p. 167-179. In A.L. Page et al (ed.) Methods of soil analysis. Part 2. 2nd ed. ASA and SSSA, Madison, WI.

Rochette, P., D.A. Angers, and D. Cote. 2000a. Soil carbon and nitrogen dynamics following application of pig slurry for the 19th consecutive year: I. Carbon dioxide fluxes and microbial biomass carbon. Soil Sci. Soc. Am. J. 64:1389-1395.

Rochette, P., E. van Bochove, D. Prevost, D.A. Angers, D. Cote, and N. Bertrand. 2000b. Soil carbon and nitrogen dynamics following application of pig slurry for the 19th consecutive year: II. Nitrous oxide fluxes and mineral nitrogen. Soil Sci. Soc. Am. J. 64: 1396-1403.

Schepers, J.S., D.D. Francis, and M.T. Thompson. 1989. Simultaneous determination of total C, total $\mathrm{N}$, and ${ }^{15} \mathrm{~N}$ on soil and plant material. Commun. Soil Sci. Plant Anal. 20:949-959.

Sharpley, A., T.C. Daniel, J.T. Sims, and D.H. Pote. 1996. Determining environmentally sound soil phosphorus levels. J. Soil Water Conserv. 51:160-166.

Sharpley, A., J.J. Meisinger, A. Breeuwsma, J.T. Sims, T.C. Daniel, and J.S. Schepers. 1998. Impact of animal manure management on ground and surface water quality. p. 173-242. In J.L. Hatfield and B.A. Stewart (ed.) Animal waste utilization: Effective use of manure as a soil resource. Ann Arbor Press, Chelsea, MI.

Smith, J.L., and J.W. Doran. 1996. Measurement and use of $\mathrm{pH}$ and electrical conductivity for soil quality analysis. p. 169-185. In J.W. Doran and A.J. Jones (ed.) Methods for assessing soil quality. SSSA Spec. Publ. 49. SSSA, Madison, WI.

Varvel, G.E. 1994. Rotation and nitrogen fertilization effects on changes in soil carbon and nitrogen. Agron. J. 86:319-325.

Wander, M.M., S.J. Traina, B.R. Stinner, and S.E. Peters. 1994. Organic and conventional management effects on biologically active soil organic matter pools. Soil Sci. Soc. Am. J. 58:1130-1139.

Weil, R.R., K.R. Islam, M.A. Stine, J.B. Gruver, and S.E. SampsonLeibig. 2003. Estimating active carbon for soil quality assessment: A simplified method for laboratory and field use. Am. J. Alternative Agric. 18:3-17.

Wienhold, B.J., and P.S. Miller. 2004. Phosphorus characterization in manure from swine fed traditional and low phytate corn diets. J. Environ. Qual. 33:389-393. 